\title{
GAMBARAN RUANG PENYIMPANAN DOKUMEN REKAM MEDIS RAWAT INAP
}

\author{
${ }^{1}$ Hany Ardiani, ${ }^{2}$ Arief Tarmansyah Iman \\ 1,2, Poltekkes Kemenkes Tasikmalaya \\ e-mail: hanyardiani@gmail.com
}

\begin{abstract}
Abstrak
Rumah Sakit Umum Daerah (RSUD) Majenang sedang dalam persiapan untuk menghadapi akreditasi rumah sakit oleh lembaga KARS 2012. Unit rekam medis adalah unit yang berperan penting dalam akreditasi, khususnya pada bagian ruang penyimpanan (filing). Penelitian ini bertujan untuk mengetahui gambaran keadaan ruang penyimpanan dokumen rekam medis rawat inap sesuai dengan standar akreditasi 2012 dalam menghadapi akreditasi KARS di RSUD Majenang. Jenis penelitian ini adalah deskriptif kualitatif. Teknik pengumpulan data menggunakan observasi dan wawancara mendalam kepada petugas unit kerja rekam medis. Hasil penelitian diketahui : a. Kebijakan tentang standar akreditasi MKI.11, 12, dan 16 sudah ada tetapi belum disahkan dan masih berupa draft; b. Standar akreditasi MKI.11 pengembalian DRM lebih dari 2x24, sudah ada proses dan tindakan untuk pelanggar, tidak ada petugas filing, ruang penyimpanan pertama panas dengan suhu 29,90C; c. MKI.12 pemusnahan dokumen belum dilaksanakan; $d$. MKI.16 masih ditemukan DRM yang rusak, ruang penyimpanan selalu dikunci, sarana dan prasarana keamanan ruang penyimpanan masih kurang. Ruang penyimpanan masih perlu diperbaiki yaitu kebijakan Direktur revisi 2015 segera disahkan, adanya petugas khusus, penataan dan perbaikan, penyediaan ruang DRM in-aktif, kebersihan dilakukan dengan rutin, penambahan sarana dan prasana keamanan.

Kata kunci : Ruang Penyimpanan, Rekam Medis.

Abstract

General Hospital of Regional of Majenang (RSUD) is in preparation for the accreditation of hospitals by KARS. Medical records Unit is one unit that plays an important role in the accreditation, including in filing system. This study purpose to describe storage unit of filling system inpatient medical record documents in accordance with accreditation standards in 2012. This type of research is qualitative descriptive. Data collection technique used observation and indepth interviews to officers who working at medical record unit. The survey results revealed: policy on accreditation standards MKI.11, 12, and 16 are already there but not finalized and is still in draft; MKI.11 accreditation standards medical record document returns more than $2 \times 24$, existing processes and measures, there is no filing officer, the temperatures in filling room is 29,90C; MKI.12 document destruction has not been implemented;. MKI.16 still found the broken DRM, fillinr room is always locked, facilities and infrastructure security is still lacking. Filling room still needs to be improved, policy made by director must be finish soon, need more, cleanliness done routinely, as addition of facilities and infrastructures security.
\end{abstract}

Keywords : Filing room, Medical Record.

\section{PENDAHULUAN}

Akreditasi rumah sakit saat ini menggunakan Standar Komisi Akreditasi Rumah Sakit (KARS) versi 2012 terdiri dari empat kelompok yaitu kelompok standar pelayanan berfokus pada pasien, kelompok standarmanajemen rumah sakit, kelompok sasaran keselamatan pasien, dan sasaran program MDG's.Sasaran tersebut agar bisa terwujud maka perlu didukung adanya unit- unit pembantu yang mempunyai tugas spesifik, diantaranya unit rekam medis.

Unit rekam medis pada pelayanan kesehatan sangat berperan untuk memelihara dan menjaga dokumen rekam medis pasien serta bertanggung jawab terhadap pengelolaan data pasien menjadi informasi kesehatan yang berguna bagi pegambilan keputusan. Hal ini disebutkan dalam peraturan Undang-Undang No 44 tahun 2009 
Pasal 29 ayat 1 huruf $\mathrm{h}$ setiap rumah sakit mempunyai kewajiban menyelenggarakan rekam medis. Selain kewajiban pelayanan rekam medis di fasilitas pelayanan kesehatan juga menjadi salah satu penilaian pada proses akreditasi (Budi, 2011). Salah satu sarana tersebut adalah dengan menyediakan ruang penyimpanan dokumen rekam medis.

Rumah sakit juga mempunyai standar ruang penyimpanan meliputi suhu, luas ruangan penyimpanan, jarak, aman, pencahayaan, debu dan vektor penyakit (Rustiyanto \& Rahayu, 2011). Hasil penelitian Wihana (2015) di RSUD dr. Soekardjo Kota Tasikmalaya menunjukan bahwa keadaan ruang penyimpanan dokumen rekam medis rawat inap masih belum ideal dari segi luas ruangan dan banyaknya rak masih belum mampu menampung banyaknya dokumen rekam medis. Jarak antar rak terlalu sempit, sehingga akan menggangu kenyamanan petugas. Keamanan dokumen tetap dilindungi baik fisik maupun isinya karena dokumen rekam medis bersifat rahasia. Pencahayaan bagus yaitu dengan kontras dari lampu yang cukup terang. Terdapat beberapa vektor yang membuat beberapa dokumen rekam medis rawat inap rusak.

Berdasarkan hasil studi pendahuluan yang telah dilakukan oleh peneliti pada tanggal 6 dan 9 Februari 2016 terhadap ruang penyimpanan rawat inap dan petugas rekam medis yaitu RSUD Majenang memiliki tiga (3) ruang penyimpanan dokumen rekam medis rawat inap, kondisi tata ruang penyimpanan rekam medis pertama dan kedua Rumah Sakit Umum Daerah (RSUD) Majenang yang berada di lantai dua berdekatan dengan aula belum sesuai dengan kondisi tata ruang yang ideal bagi pegawai yaitu dengan kondisi banyaknya dokumen masih ada yang disimpan di dalam kardus, diletakan di rak penyimpanan namun masih ada beberapa dokumen yang diletakkan di lantai sehingga pencarian dokumen rekam medis menjadi lama dan bahkan tidak ketemu, jendela dan ventilasi yang tertutup rak menyebabkan cahaya dan udara yang masuk kedalam ruangan berkurang, ruangan menjadi gelap, pengap dan belum diterapkannya prosedur keselamatan, kesehatan dan keamanan kerja (K3).

Prosedur K3 merupakan tahap atau proses suatu kegiatan untuk menyelesaikan aktivitas atau metode (cara) langkah demi langkah secara pasti dalam pekerjaan dengan memperhatikan keselamatan, kesehatan, dan keamanan (Honiarti, 2010). Sedangkan dari segi keamanan ruang penyimpanan RSUD Majenang juga masih kurang yaitu belum diterapkan kebijakan tentang keamanan ruang penyimpanan dokumen rekam medis rawat inap, tidak adanya alat pelindung diri seprti masker, sarung tangan, peringatan tanda selain petugas ruang penyimpanan dilarang masuk, alat pemadam kebakaran.

Melihat kondisi ruang penyimpanan yang ada pada saat ini jika dihubungkan dengan akan dilaksanakannya proses akreditasi KARS di RSUD Majenang, maka perlu diketahui gambaran mengenai ruang penyimpanan. Tujuan penelitian ini adalah mengetahui gambaran keadaan ruang penyimpanan dokumen rekam medis Rawat inap RSUD Majenang sesuai dengan akreditasi 2012 dalam menghadapi akreditasi rumah sakit tahun 2016 .

\section{METODE PENELITIAN}

Jenis penelitian adalah deskriptif kualitatif dengan pendekatan studi kasus. Subjek dalam penelitian 3 petugas ruang penyimpanan Rawat Inap RSUD Majenang. Objek dalam penelitian ini adalah ruang penyimpanan Rawat Inap di RSUD Majenang. Instrumen pengumpulan data adalah pedoman wawancara berupa daftar pertanyaan yang sudah tersusun dengan baik untuk mengetahui persiapan ruang penyimpanan dalam menghadapi akreditasi KARS sesuai dengan standar akreditasi 2012 elemen MKI.11, MKI.12, MKI.16. Dan pedoman observasi penelitian ini megamati tiga ruang penyimpanan dokumen rekam medis rawat inap sesuai dengan standar akreditasi 2012. Analisis data dengan menggunakan konsesp Miles dan Huberman terdiri dari data reduction, data display, conclusion drawing. 
HASIL PENELITIAN

Hasil Observasi

Hasil observasi dapat dilihat pada tabel 1.

Tabel 1. Hasil Observasi Keadaan Ruang Penyimpanan Dokumen Rekam Medis Rawat Inap Di RSUD Majenang Kabupaten Cilacap

\begin{tabular}{|c|c|c|c|}
\hline \multirow{2}{*}{ Kriteria } & \multicolumn{3}{|c|}{ Hasil Observasi Ruang Penyimpanan } \\
\hline & 1 & 2 & 3 \\
\hline $\begin{array}{l}\text { Dokumen Kebijakan } \\
\text { Keamanan ruang } \\
\text { penyimpanan : kebijakan } \\
\text { Sistem Penyimpanan }\end{array}$ & $\begin{array}{l}\text { Ada, masih berupa draft } \\
\text { dan belum di sahkan } \\
\text { Direktur (terlampir). }\end{array}$ & $\begin{array}{l}\text { Ada, masih berupa draft } \\
\text { dan belum di sahkan } \\
\text { Direktur (terlampir). }\end{array}$ & $\begin{array}{l}\text { Ada, masih berupa } \\
\text { draft dan belum di } \\
\text { sahkan Direktur } \\
\text { (terlampir). }\end{array}$ \\
\hline a. SPO & Tidak ada. & Tidak ada. & Tidak ada. \\
\hline $\begin{array}{l}\text { b. APD } \\
\text { - Masker } \\
\text { - Alcohol } \\
\end{array}$ & Ada. & Ada. & Ada. \\
\hline c. Luas Ruangan & $\begin{array}{l}\text {-Panjang : } 8 \text { meter } \\
\text {-Lebar : 6,70 meter } \\
\text {-Tinggi : 3,65 meter }\end{array}$ & $\begin{array}{l}\text {-Panjang : } 8 \text { meter } \\
\text {-Lebar: } 6 \text { meter } \\
\text {-Tinggi: 3,65 meter }\end{array}$ & $\begin{array}{l}\text {-Panjang: 10,16 meter } \\
\text {-Lebar: 3,32 meter } \\
\text {-Tinggi: 3,70 meter }\end{array}$ \\
\hline $\begin{array}{l}\text { d. Jarak antara lemari } \\
\text { satu dengan lemari lain }\end{array}$ & $75 \mathrm{~cm}$ & $114 \mathrm{~cm}$ & Belum ada lemari (rak) \\
\hline e. Vector Penyakit & Ada (kecoa) & Tidak Ada & Tidak ada \\
\hline $\begin{array}{l}\text { f. Alat/sarana menjaga } \\
\text { keamanan } \\
\text { Tanda peringatan }\end{array}$ & $\begin{array}{l}\text { Ada, tentang dilarang } \\
\text { merokok }\end{array}$ & Tidak ada & $\begin{array}{l}\text { Ada, selain petugas } \\
\text { dilarang masuk }\end{array}$ \\
\hline $\begin{array}{l}\text { Alat pemadam } \\
\text { kebakaran }\end{array}$ & $\begin{array}{l}\text { Ada, di samping ruang } \\
\text { penyimpanan }\end{array}$ & $\begin{array}{l}\text { Ada, di samping ruang } \\
\text { penyimpanan }\end{array}$ & Tidak ada \\
\hline Dokumen Kebijakan & Ada kebijakan tentang & Ada kebijakan tentang & Ada kebijakan tentang \\
\hline Keamanan informasi & $\begin{array}{l}\text { Sistem peminjaman berupa } \\
\text { draft tapi belum di sahkan } \\
\text { Direktur. (terlampir) }\end{array}$ & $\begin{array}{l}\text { Sistem peminjaman } \\
\text { berupa draft tapi belum } \\
\text { di sahkan Direktur. }\end{array}$ & $\begin{array}{l}\text { Sistem peminjaman } \\
\text { berupa draft tapi belum } \\
\text { di sahkan Direktur. }\end{array}$ \\
\hline SPO hak akses DRM & Tidak ada & Tidak ada & Tidak ada \\
\hline $\begin{array}{l}\text { Kebijakan Direktur alur } \\
\text { peminjaman DRM }\end{array}$ & $\begin{array}{l}\text { Ada, masih berupa draft } \\
\text { dan belum disahkan. }\end{array}$ & $\begin{array}{l}\text { Ada, masih berupa draft } \\
\text { dan belum disahkan. }\end{array}$ & $\begin{array}{l}\text { Ada, masih berupa } \\
\text { draft dan belum } \\
\text { disahkan. }\end{array}$ \\
\hline $\begin{array}{l}\text { Dokumen Kebijakan } \\
\text { masa retensi/ } \\
\text { penyimpanan dokumen : }\end{array}$ & $\begin{array}{l}\text { Ada kebijakan Direktur } \\
\text { tentang Sistem } \\
\text { Pemusnahan DRM, masih } \\
\text { berupa draft dan belum } \\
\text { disahkan. }\end{array}$ & $\begin{array}{l}\text { Ada kebijakan Direktur } \\
\text { tentang Sistem } \\
\text { Pemusnahan DRM, } \\
\text { masih berupa draft dan } \\
\text { belum disahkan. }\end{array}$ & $\begin{array}{l}\text { Ada kebijakan Direktur } \\
\text { tentang Sistem } \\
\text { Pemusnahan DRM, } \\
\text { masih berupa draft dan } \\
\text { belum disahkan. }\end{array}$ \\
\hline $\begin{array}{l}\text { Dokumen Kebijakan } \\
\text { Perlindungan dokumen } \\
\text { dari kehilangan, } \\
\text { kerusakan, gangguan, } \\
\text { akses dan penggunaan } \\
\text { oleh yang tidak berhak: }\end{array}$ & $\begin{array}{l}\text { Ada kebijakan tentang } \\
\text { Sistem peminjaman } \\
\text { berupa draft tapi belum } \\
\text { di sahkan Direktur } \\
\text { (terlampir). }\end{array}$ & $\begin{array}{l}\text { Ada kebijakan } \\
\text { tentang Sistem } \\
\text { peminjaman berupa } \\
\text { draft tapi belum di } \\
\text { sahkan Direktur } \\
\text { (terlampir). }\end{array}$ & $\begin{array}{l}\text { Ada kebijakan } \\
\text { tentang Sistem } \\
\text { peminjaman berupa } \\
\text { draft tapi belum di } \\
\text { sahkan Direktur } \\
\text { (terlampir). }\end{array}$ \\
\hline a. SPO & Tidak ada & Tidak ada & Tidak ada \\
\hline $\begin{array}{l}\text { b. Buku ekspedisi atau } \\
\text { buku register peminjaman }\end{array}$ & Ada & Ada & Ada \\
\hline c. Tracer & Tidak ada & Tidak ada & Tidak ada \\
\hline $\begin{array}{l}\text { d. SPO pengembalian } \\
\text { DRM }\end{array}$ & Ada & Ada & Ada \\
\hline e. Suhu (waktu 5 menit) & $29,9^{\circ} \mathrm{C}$ dan $78 \%$ & $27,9^{0} \mathrm{C}$ dan $63 \%$ & $26,7^{0} \mathrm{C}$ dan $60 \%$ \\
\hline $\begin{array}{ll}\text { f. } & \text { Pencahayaan } \\
\text { - Lampu menyala } \\
\text { - Lampu mati } \\
\end{array}$ & $\begin{array}{l}\text { jam } 10.56 \\
368 \operatorname{lux} \\
352 \operatorname{lux} \\
\end{array}$ & $\begin{array}{l}\text { Jam } 11.32 \\
505 \operatorname{lux} \\
390 \operatorname{lux} \\
\end{array}$ & $\begin{array}{l}\text { Jam } 10.30 \\
950 \operatorname{lux} \\
840 \operatorname{lux} \\
\end{array}$ \\
\hline
\end{tabular}




\section{Hasil Wawancara}

Keadaan Ruang Penyimpanan Dokumen Rekam Medis Rawat Inap sesuai standar akreditasi 2012 MKI.11, MKI.12, MKI.16.

\section{MKI.11 Kemanan Informasi Termasuk} Integritas Data Dijaga

Adanya Kebijakan pelepasan informasi medis dalam rangka menjaga keamanan informasi medis pada dokumen rekam medis rawat inap di RSUD Majenang. Semua informan menjelaskan bahwa kebijakan pelepasan informasi RSUD Majenang belum ada sehingga petugas berpedoman kepada kebijakan filing. Hal ini sesuai dengan informan 1 yang menjelaskan bahwa kebijakan pelepasan informasi terdapat pada kebijakan tentang filing.

Semua informan menyatakan untuk alur peminjaman dokumen rekam medis harus membawa surat kuasa dari pasien atau pihak asuransi dan mendapatkan persetujuan dari Direktur setelah disetujui surat tersebut diberikan kembali ke URM. Alur peminjaman tersebut sudah ada kebijakan Direktur tetapi ada satu informan yang belum megetahui kebijakan tersebut.

Pengembalian DRM masih ada yang lebih dari 2×24 jam karena DRM masih dipergunakan untuk kepentingan lain seperti akan dilaksanakan audit. Tindakan petugas RM terhadap petugas yang meminjam tetapi tidak menjaga keamanan DRM tersebut yaitu ketiga informan menjawab dengan cara menghubungi masing-masing ruangan dan ditegur.

Proses tindak lanjut yang dilakukan petugas yaitu petugas RM melaporkan petugas yang melanggar keamanan dan kerahasian dokumen kepada kepala bangsal untuk proses tindakan selanjutnya. Seluruh informan menyatakan bahwa kebijakan terbaru tentang keamanan ruang penyimpanan belum ada, tetapi mengacu kepada kebijakan Direktur yang baru direvisi 2015 tentang sistem penyimpanan yang berpedoman pada kebijakan lama yaitu 2007 sehingga kebijakan yang baru masih berupa draft dan belum di sahkan oleh Direktur.

Adanya Alur penyimpanan dokumen rekam medis rawat inap sebagai bentuk pengendalian keamanan data pasien. Sesuai dengan pernyataan informan 2 yang dikutip sebagai berikut:

"Untuk alur mah setahu aku berkas dari ruangan ke $R M$ dulu, setelah itu di RM baru diassembling, disensus dan lainlain. Apabila ada yang kurang lengkap dikembalikan ke ruangan. Apabila lengkap langsung disimpan di rak filing."

Secara keseluruhan untuk menjaga keamanan ruang penyimpanan adalah petugas rekam medis, namun ada satu informan menyebutkan bahwa security juga ikut menjaga. Hal ini sesuai dengan pernyataan informan 2 yang dikutip sebagai berikut; "RM dan securiti nya keliling".

Adanya cara penjagaan kebersihan ruang penyimpanan dokumen rekam medis rawat inap RSUD Majenang dari suhu, debu, vektor penyakit. Semua informan menjawab untuk kebersihan ruang penyimpanan dijaga oleh Cleaning Service (CS) karena tidak ada petugas khusus ruang penyimpanan.

\section{MKI.12 Masa Retensi / Penyimpanan Dokumen, Data dan Informasi}

Kebijakan masa retensi di RSUD Majenang sudah ada, tetapi belum dilaksanakan dari awal rumah sakit berdiri tahun 1997 dan pelaksanaan penggunaan DRM pertama dilaksanakan tahun 2008 karena terkendala oleh SDM yang kurang memadai, belum tersedianya ruang penyimpanan untuk dokumen in-aktif, dan penyimpanan belum sesuai sehingga untuk pemisahan dokumen aktif ke in-aktif belum dilaksanakan.

Begitu juga dengan pemusnahan dan cara pemusnahan belum dilaksanan karena pemisahan DRM aktif ke in-aktif belum dilakukan dan belum tersedianya ruang penyimpanan DRM in-aktif. Belum adanya Kebijakan tentang perlindungan catatan dan informasi dari kehilangan, kerusakan, gangguan, serta akses dan penggunaan oleh yang tidak berhak. Mempunyai permasalahan tersebut semua informan belum mengetahui adanya kebijakan khusus, sejauh ini acuannya dari SPO yang isinya tentang siapa yang boleh mengakses informasi untuk DRM. 


\section{PEMBAHASAN}

Kebutuhan akan informasi kesehatan pasien merupakan kebutuhan yang sangat mendasar. Salah satu sumber informasi pasien adalah dokumen rekam medis, dalam proses pengambilan keputusan tentunya membutuhkan data-data yang diolah menjadi informasi kemudian digunakan sebagai bahan pertimbangan dalam proses pengambilan keputusan. Dokumen perlu mendapatkan perhatian khusus, sehingga dokumen rekam medis di rumah sakit benar-benar menunjukan peran yang sesuai dan dapat mendukung dalam pengambilan keputusan dalam melakukan tindakan medis terhadap pasien.

Kebijakan sudah dilaksanakan, hal ini sudah sesuai dengan standar akreditasi 2012 dimana salah satu elemen penilaiannya adalah rumah sakit mempunyai kebijakan tertulis untuk mengatur keamanan informasi, termasuk integritas data yang didasarkan pada atau konsisten dengan peraturan dan perundang-undangan yang berlaku (Kemenkes, 2011).

Penyampaian informasi rekam medis kepada orang atau badan yang diberi kuasa pasien, misalnya pihak asuransi yang menanggung biaya pengobatan, diperlukan surat kuasa pasien atau yang bertanggung jawab terhadap pasien tersebut (Shofari, 2002). RSUD Majenang sudah menerapkan sistem tersebut dimana setiap peminjaman DRM harus membawa surat kuasa dari asien.

Salah satu aspek untuk menjaga keamanan informasi pasien adalah dengan menentukan siapa yang berwenang untuk mendapatkan berkas rekam medis klinis pasien dan melakukan pengisian berkas ke dalam rekam medis pasien tersebut (Kemenkes, 2011).

Rekam medis yang baik juga dipengaruhi oleh kualitas pelayanan yang baik juga dan salah satu faktor yang mendukung pelayanan rekam medis yang baik yaitu ketepatan waktu pengembalian rekam medis karena apabila tidak tepat waktu dapat mempengaruhi lama waktu pasien untuk mendapatkan pelayanan menjadi lama dan pengolahan data menjadi terhambat. Ketepatan waktu adalah keadaan betul atau benar dalam mengembalikan rekam medis ke tempat asalnya/semulanya dengan waktu yang sudah ditetapkan. Semua dokumen rekam medis yang telah selesai dipakai di poliklinik/ruangan yang memerlukan harus segera diambil kembali atau dikembalikan ke unit rekam medis dengan ketentuan yang tercantum dalam protap pengembalian dokumen rekam medis.

Setiap dokumen rekam medis yang dikembalikan dari ruang rawat inap ke unit rekam medis harus disusun sesuai ketentuan yang berlaku di rumah sakit. Batas waktu penyelesaian pengisian dokumen rekam medis pasien rawat inap paling lama $1 \times 24$ jam setelah pasien keluar dari rumah sakit dan dokumen rekam medis harus segera dikembalikan ke unit rekam medis. Pengembalian dokumen rekam medis rawat inap pada bagian assembling dikatakan terlambat jika $>1 \times 24$ jam, pencatatan hasil pelayanan ke dalam formulir rekam medis seringkali tidak lengkap, padahal salah satu syarat untuk disimpan Dokumen Rekam Medis (DRM) harus sudah terisi dengan lengkap. Oleh karena itu diperlukan sistem pengendalian ketidaklengkapan isi rekam medis ( Dirjen Yanmed, 2006).

Berdasarkan hasil wawancara petugas yang meminjam ada yang belum patuh karena hal tersebut sesuai dengan kebutuhan dokumen yang digunakan untuk kepentingan apa, dan ada yang sudah patuh terhadap kebijakan pengembalian dokumen rekam medis rawat inap yaitu 2×24 jam hal tersebut sudah sesuai dengan kebijakan Direktur tentang sistem pengembalian DRM dan SPO prosedur pengembalian dokumen rekam medis rawat inap (lampiran 9 \& 10) yang masih berupa draft dan belum disahkan oleh Direktur karena kebijakan dan SPO tersebut baru direvisi dari tahun 2007 ke tahun 2015

Hal tersebut belum sesuai dengan pernyataan Ramdani (2014) yaitu berdasarkan kebijakan yang ditetapkan PerMenKes dan SOP berkas rekam medis rawat inap harus kembali ke ruang instansi rekam medis dalam waktu $2 \times 24$ jam setelah pasien pulang rawat. 
Adanya cara penjagaan kebersihan ruang penyimpanan dokumen rekam medis rawat inap RSUD Majenang dari suhu, debu, vektor penyakit. Suhu di ketiga ruang penyimpanan ada satu ruangan yang belum sesuai standar yaitu $29,90 \mathrm{C}$ dan kelembaban $78 \%$ ruangan menjadi panas. Dan ruang penyimpanan di RSUD Majenang masih menggun akan ruangan bekas aula yang di bagi menjadi dua sehingga ruangan belum cukup untuk menampung dokumen. Hal tersebut terlihat dari masih adanya penumpukan dokumen di setiap ruang penyimpanan. Jarak antar lemari satu dengan yang lain di dua ruang penyimpanan lantai atas diketahui $75 \mathrm{~cm}$ dan $114 \mathrm{~cm}$.

Hal tersebut belum sesuai dengan pernyataan menurut Rustiyanto dan Rahayu (2011) dimana bagian petugas filing berfungsi sebagai penjaga keamanan dan kerahasiaan DRM, melindungi DRM dari bahaya fisik, kimiawi, biologi. Kegiatan membersihkan ruang penyimpanan dilakukan pada pagi dan sore hari dengan menggunakan kain pel basah atau pompa hampa, selain itu standar suhu ruang penyimpanan adalah 18-280C sedangkan kelembaban 40\%-60\% karena negara kita negara tropis dan jarak juga belum sesuai standar yaitu dengan standar $180 \mathrm{~cm}-200 \mathrm{~cm}$.

Dampak yang terjadi dari kondisi ruang penyimpanan sekarang yaitu apabila temperatur yang terlampau dingin akan mengakibatkan gairah kerja menurun. Sedangkan temperatur udara yang terlampau panas, akan mengakibatkan cepat timbul kelelahan tubuh dan dalam bekerja cenderung membuat banyak kesalahan (Gumilar, 2014).

Pernyataan Sakinafisa (2015) yang menyebutkan Petugas rekam medis berperan dalam menyiapkan dokumen-dokumen yang dibutuhkan, mengevaluasi standar penyelenggaraan rekam medis di Rumah Sakit dengan standar KARS dan merevisinya jika masih ada kekurangan. Kutipan terdapat pada poin 2 yang isinya "dilarang mengutip isi rekam medis oleh siapun kecuali yang telah ditetapkan oleh peraturan-peraturan yang berlaku, hanya petugas rekam medis yang hanya di ijinkan masuk ruang penyimpanan berkas rekam medis" (lampiran 7). Hal tersebut sesuai dengan informan kunci yang menyebutkan siapa yang boleh mengakses informasi.

Secara umum informasi dalam rekam medis bersifat rahasia, artinya tidak semua orang dapat membaca dan mengetahuinya. Dalam pasal 10 ayat (1) Permenkes RI Nomor 269/Menkes/Per/III/2008 tentang rekam medis mengatakan bahwainformasi tentang identitas, diagnosis, riwayat penyakit, riwayat pemeriksaan, dan riwayat pengobatan pasien harus dijaga kerahasiaannya oleh dokter, dokter gigi, tenaga kesehatan tertentu, petugas pengelola, dan pimpinan sarana pelayanan kesehatan.

Kerahasiaan rekam medis menurut Permenkes tersebut tidak mutlak bersifat rahasia. Hal itu dikarenakan meskipun tetap ada kewajiban bagi dokter, dokter gigi, tenaga kesehatan tertentu, petugas pengelola dan pimpinan pelayanan kesehatan untuk menjaga kerahasiaan informasi dalam rekam medis, kewajiban tersebut ada batasnya. Adapun yang wajib dijaga kerahasiaannya adalah informasi tentang identitas, diagnosis, riwayat penyakit, riwayat pemeriksaan dan riwayat pengobatan.

Bentuk kerusakan atau gangguan perlindungan informasi DRM: Kerusakan DRM pada umumnya yang paling sering terjadi adalah sobek, terserang jamur, terkena air dan terbakar (Sugiarto \& Wahyono, 2015). Menurut Sugiarto dan Wahyono (2005), yaitu faktor-faktor penyebab kerusakan yaitu faktor intrinsik yang berasal dari benda arsip sendiri misalnya kualitas kertas pengaruh tinta dan pengaruh lem perekat. Faktor ekstrinsik yang berasal dari, pertama lingkungan fisik yaitu suhu, sinar matahari, polusi udara dan debu, kedua biologis yaitu kerusakan akibat vektor penyakit, ketiga kimiawi kerusakan akibat kualitas kandungan bahan kimia, dan terakhir kelalaian manusia akibat percikan bara api, tumpahan atau percikan minuman dan sebagainya.

Hal tersebut sudah sesuai menurut pernyataan Rustiyanto \& Rahayu (2011) yaitu melindungi dokumen dari bahaya kerusakan 
fisik, kimiawi, biologi dan terdapat tanda peringatan di ruang penyimpanan. Tetapi hal tersebut juga belum cukup dan belum sesuai dengan pernyataan Kemenkes (2011) tentang standar akreditasi berdasarkan kelompok Manajemen dan Fasilitas Kesehatan (MFK) pada standar MFK.7.2 tentang pengamanan kebakaran yaitu rumah sakit secara khusus rumah sakit

Pengamanan arsip ialah usaha penjagaan agar benda arsip tidak hilang dan agar isi atau informasinya tidak samai ketahuan oleh orang yang tidak berhak, misalnya usaha pengamanannya harus pengendalian dalam peminjaman arsip dilakukan (Sugiarto \& Wahyono, 2015).

Berdasarkan hasil observasi dan wawancara RSUD Majenang sudah baik yaitu untuk mengetahui dokumen tersebut sedang digunakan oleh dokter atau petugas lain, petugas URM menyediakan buku register peminjaman DRM.

Rustiyanto \& Rahayu (2011) menyatakan bahwa sarana dan prasarana yang dibutuhkan di bagian filing antara lain; tracer (petunjuk keluar) yaitu alat yang digunakan sebagai alat petunjuk keluar jika DRM diambil atau dipinjam untuk digunakan pihak pasien atau petugas kesehatan lain. Buku ekspedisi yang berisi tentang catatan penggunaan DRM untuk bukti serah terima peminjaman dan alat kontrol penggunaan DRM rajal. Folder DRM kosong untuk mengganti folder yang rusak.

\section{KESIMPULAN}

Berdasarkan hasil penelitian terhadap ruang penyimpanan dokumen rekam medis rawat inap di RSUD Majenang, kondisi ruang penyimpanan belum siap untuk menghadapi akreditasi KARS 2012. Kebijakan tentang sistem pemusnahan belum dilaksanakan karena minimnya tempat penyimpanan, kurangnya SDM, selain itu kebijakan tersebut masih berupa draft dan belum disahkan oleh Direktur karena masih dalam tahap revisi dari 2007 ke 2015.

Kebijakan tentang perlindungan catatan dan informasi dari kehilangan, kerusakan, gangguan, serta akses dan penggunaan oleh yang tidak berhak :Petugas berpedoman pada kebijakan Direktur tentang sistem penyimpanan, tetapi kebijakan tersebut masih berupa draft dan belum disahkan direkur karena masih dalam revisi dari 2007 ke 2015. Masih ada DRM yang sobek foldernya. Ruang penyimpanan sudah dikunci, sudah ada alat pemadam kebakaran, sudah ada tanda peringatan dan APD.

\section{Daftar Pustaka}

Alamsyah, D. (2011). Manajemen Pelayanan Kesehatan. Yogyakarta: Nuha Medika.

Budi, S.C. (2011). Manajemen Unit Kerja Rekam Medis. Yogyakarta: Quantum Sinergis Media.

Departemen Kesehatan Republik Indoesia. (1997). Pedoman Penyelenggaraan Pelayanan Di Rumah Sakit. Jakarta: Departemen Kesehatan RI. (2006). Pengelolaan Rekam Medis Rumah sakit di Indonesia Revisi II.

Jakarta : Direktorat Jendral Pelayanan Medik.

(2008). Pedoman Pengelolaan Rekam Medis Rumah Sakit Di Indonesia. Jakarta: Direktorat Jendral Pelayanan Medik.

Dewi, R.P. (2008). Modul Menghasilkan Dokumen Sederhana. Jakarta: Yudhistira.

Endang, S.R. et al. (2010). Modul Memahami Prinsip-Prinsip Penyelenggaraan Administrasi Perkantoran Untuk SMK Dan MAK. Jakarta: Erlangga.

Gumilar, R.F. (2014). Tata Ruang Penyimpanan Dokumen Rekam Medis in Aktif Di Rumah Sakit Umum Kota Banjar. Karya Tulis IImiah DIII Pikes Poltekkes Kemenkes Tasikmalaya. Tasikmalaya : tidak diterbitkan.

Hatta, G. (2013). Pedoman Manajemen Informasi Kesehatan di Sarana Pelayanan kesehatan. Jakarta: Universitas Indonesia (UI-Press).

Honiatri, E. et al(2010). Menerapkan Keselelamatan, Kesehatan, Keamanan Kerja Dan Lingkungan Hidup (K3LH). Bandung: Armico.

Kementrian Kesehatan Republik Indonesia. (2011). Standar Akreditasi Rumah Sakit. Jakarta: Kemenkes RI. 
Keputusan Menteri Republik Indonesia Nomor: 129/Menkes/SK/II/2008. Standar Pelayanan Minimal Rumah Sakit. Jakarta.

Nurdini, R. (2013). Persepsi Petugas Terhadap Tata Ruang Penyimpanan Rekam Medis Di Rumah Sakit jasa Kartini Kota Tasikmalaya. Karya Tulis IImiah DIII Pikes Poltekkes Kemenkes Tasikmalaya: tidak diterbitkan.

Peraturan Kepala Arsip Nasional Republik Indonesia. Nomor 06 Tahun 2005 Tentang Pedoman Perlindungan, Pengamanan Dan Penyelamatan Dokumen/Arsip Vital Negara. [Online]. Tersedia: http://upma.vokasi.ui.ac.id/ $\quad[19$ Maret 2016].

, Nomor 16 Tahun 2012 Tentang Pedoman Pengelolaan Arsip Kartografi dan Kearsitekturan.

Peraturan Menteri Kesehatan Republik Indonesia Nomor 417/MENKES/PER/II/2011 Tentang Komisi Akreditasi Rumah Sakit. Jakarta.

Nomor 012 tahun 2012 Tentang Akreditasi Rumah Sakit.

Nomor 269/MENKES/PER/III/2008 Tentang Rekam Medis.

Peraturan Undang-Undang Republik Indonesia. Nomor 44 Tahun 2009 Tentang Rumah Sakit.

Nomor. 43 tahun 2009 tentang Kearsiapan

Ramdani, D.F. (2014). Tinjauan Pelaksananaan Standard Operasional Prosedur (SOP) Pengembalian Dokumen Rekam Medis Rawat Inap Rumah Sakit Umum Daerah dr. Soekardjo Tahun 2014. Karya Tulis IImiah DIII Pikes Poltekkes Kemenkes Tasikmalaya. Tasikmalaya : tidak diterbitkan
Rustiyanto, E. (2009). Etika Profesi Perekam Medis dan Informasi Kesehatan. Yogyakarta: Graha IImu.

Rustiyanto, E \& Rahayu, W.A. (2011). Manajemen Filing Dokumen Rekam Medis Dan Informasi Kesehatan. Yogyakarta: Politeknik Kesehatan Permata Indonesia.

Sakinafisa, Y. (2015). Peran Petugas Rekam Medis Dalam Pelaksanaan Akreditasi Komisi Akreditasi Rumah Sakit (Kars) Di Rsup Dr. Hasan Sadikin Bandung. Karya Tulis IImiah DIII Pikes Poltekkes Kemenkes Tasikmalaya: tidak diterbitkan.

Sugiarto, A \& Wahyono, T. (2005). Manajemen Kearsipan Modern Dari Konvensional Ke Basis Komputer. Yogyakarta : Gava Media

Sugiyono. (2009). Metode Penelitian Kuantitatif, Kualitatif dan R\&D. Bandung: Alfabeta. Kuantitatif, Kualitatif dan Kombinasi (Mixed Methods). Bandung: Alfabeta.

Sujarweni, V.W. (2014). Metodologi Penelitian. Yogyakarta: Pustaka Baru Press.

Wihana, R. (2015). Evaluasi Keadaan Ruang Penyimpanan Dokumen Rekam Medis Rawat Inap Di Rumah Sakit Umum Daerah dr. Soekardjo Kota Tasikmalaya. Buletin Media Informasi Poltekkes Kemenkes Tasikmalaya. Tasikmalaya: Politeknik Kesehatan Kementrian Kesehatan Tasikmalaya.

Yuniwati, K.R. (2014). Jurnal Evaluasi Penyelenggaraan Rekam Medis Pasien Dalam Pemenuhan Standar Akreditasi Rumah Sakit Di Rumah Sakit Muhammadiyah Selogiri Wonogiri. [Online]. Tersedia: $h t t p: / / e p r i n t s . u m s . a c . i d /$ [10 Maret 2016]. 